\title{
The Capability of Village Apparatuses in Village Financial Management
}

\author{
Duwi Agustina ${ }^{1}$, Ayu Wulandari ${ }^{2}$ \\ Universitas Bangka Belitung, Indonesia ${ }^{1,2}$ \\ \{duwiagustina7@gmail.com\}
}

\begin{abstract}
This study aims to analyze the capabilities of the village apparatus in the financial management of villages in Tanjung Pandan District, Belitung Regency according to Presidential Regulation No. 2 of 2015 and how their impact on public sector organization accountability and the constraints faced. The method used in this study uses a quantitative approach that will be carried out in Perawas villages in Tanjung Pandan District, Belitung Regency. The sample used in this study is Perawas village in Tanjung Pandan Subdistrict which consisted of Village Heads, Village Secretaries, Technical Implementers (Head of Government, Head of Development, Head of Welfare and Head of Finance), and Regional Administrators totaling 50 people. Data analysis techniques through statistical test equipment in this study using data processing tools such as SmartPLS version 3.2.8. This research was conducted to determine the determinants of village financial management and its implications for accountability in order to be able to improve the quality of financial management to be better and is expected to be considered by the Village Government to achieve and improve the capabilities of the Village Apparatus.
\end{abstract}

Keywords: The Capabilities of Village Apparatus, Quality of Financial Management.

\section{Introduction}

The Village is currently placed as the spearhead of the implementation of development and improvement of community welfare. Moreover, the government is prioritizing the village economy's progress to encourage the creation of fair and equitable prosperity. The government's seriousness is evidenced by the passing of Law No. 6 of 2014 concerning Villages, which has brought significant changes to village governance. The enactment of this law by regulation makes villages no longer a part of Law Number 32 of 2004 concerning the Regional Government. Another effort undertaken by the government is to establish a National Development Agenda set out in Presidential Regulation No. 2 of 2015 concerning the National Medium-Term Development Plan, which is committed to developing Indonesia from its periphery main focuses is to accelerate village development.

Accountability or responsibility is a form of obligation for a person (leader/officer/executive) to ensure that the duties and obligations he has carried out are applicable regulations. Accountability in the Village Government involves the Village 
Government's ability to account for the activities carried out about village interest's development and management. It is essential to ensure the implementation of values such as efficiency, effectiveness, reliability, and predictability.

Table 1. Absorption of Village Funds in the Bangka Belitung Islands Province

\begin{tabular}{|c|c|c|c|c|}
\hline No & Districts & $\begin{array}{l}\text { Total } \\
\text { Village } \\
\text { Funds }\end{array}$ & Realization & Percentage \\
\hline 1 & Bangka & $51,949 \mathrm{M}$ & $48,161 \mathrm{M}$ & $93 \%$ \\
\hline 2 & Belitung & $36,381 \mathrm{M}$ & $29,396 \mathrm{M}$ & $81 \%$ \\
\hline 3 & $\begin{array}{l}\text { Bangkka } \\
\text { Barat }\end{array}$ & $49,106 \mathrm{M}$ & $46,027 \mathrm{M}$ & $94 \%$ \\
\hline 4 & $\begin{array}{l}\text { Bangka } \\
\text { Selatan }\end{array}$ & $42,336 \mathrm{M}$ & $39,078 \mathrm{M}$ & $92 \%$ \\
\hline 5 & $\begin{array}{l}\text { Bangka } \\
\text { Tengah }\end{array}$ & $46,883 \mathrm{M}$ & $44,099 \mathrm{M}$ & $94,2 \%$ \\
\hline 6 & $\begin{array}{l}\text { Belitung } \\
\text { Timux }\end{array}$ & $43,134, \mathrm{M}$ & $31,134 \mathrm{M}$ & $91 \%$ \\
\hline
\end{tabular}

Source: Prov. Kepulauan Bangka Belitung, 2018

The data above shows that Belitung Regency is in the last place in absorbing village funds, which only absorb $81 \%$ of the total village funds disbursed by the government. In line with this, the Governor of the Bangka Belitung Islands Province is very sorry because the village government, especially in Belitung Regency, has not optimized the village funds allocated by the central government. Of course, it is closely related to the Village Apparatus's capabilities and commitment to carrying out village financial management. Also, the Village Financial System's application that has not been evenly applied to villages in Belitung Regency, especially in Tanjung Pandan District, which has the most villages among other districts in Belitung Regency, has not been able to facilitate the Village Apparatus in taking responsibility for village financial management. Monitoring the use of Village Funds and other funds is also an important issue that is often discussed to achieve financial management accountability. The Village Consultative Body, as a representative of the village community, certainly plays an essential role in monitoring the use of village funds. The BPD's contribution to overseeing the implementation of financial management by the Village Apparatus is urgently needed. Based on the background description above, the writer identifies the problem's formulation, namely: Does the Village Apparatus capability influence the management of village finances?

\section{Literature Review And Hypothesis Development}

\subsection{Village and Village Government}

Based on Law Number 6 of 2014 Article 1 states that a village is a legal community unit that has a territory border of authority in regulating and managing government affairs, community interests based on community initiative, native rights, and legal rights that are recognized and respected in the State government system. Republic of Indonesia. According to law No. 6/2014, Village government is an institution that carries out matters related to government and the interests of local communities in the government system of the Unitary State of the Republic of Indonesia. The Village Head is the government in the village assisted by the village apparatus to carry out the Village Government. The village apparatus consists of the Village Secretary, Regional Implementers and Technical Implementers. Villages have the 
rights and obligations listed in Law Number 6 of 2014 concerning Villages. The village rights are: Organize and manage community interests based on the origin rights of customs and the socio-cultural values of rural communities; Establish and manage Village Institutions; and Get a source of income.

\subsection{Village Finance}

Village finance is defined as all village rights and obligations that can be valued in money and everything in the form of cash or the state of goods owned by the Village in connection with the implementation of these rights and obligations [1]. Village finance is a sub-system of state finance as stipulated in Law Number 17 of 2003, which explains that the approach used in formulating state finance is related to objects, subjects, processes, and objectives. Village finance in Permendagri No. 113 of 2014 must be managed based on the principles of transparency, accountability, participatory, and carried out in an orderly and budgetary discipline. The Village Revenue and Expenditure Budget, from now on abbreviated as APBDesa, is the village government's annual financial plan, which is discussed and agreed upon by the village government and the Village Consultative Body, and determined by village regulations [2].

According to Amalya et al., village finance, when viewed from the nature of its management, is divided into 2 (two), namely those that are directed by the Village Government in the form of non-profit APBDesa motives and those that are indirectly managed by the Village Owned Enterprises (BUMDesa) in the way of BUMDesa Revenue and Expenditure Budget which is profit motive. Permendagri No. 113 of 2014 concerning Village Financial Management has specifically arranged the village financial management cycle, consisting of the planning, implementation, and accountability phases of village finances. According to Article 24 of Law Number 6 the Year 2014 concerning Villages, Village Government is the Village Head or referred to by another name assisted by the Village Official or referred to by another name. Thus, the Village Apparatus includes everyone involved in the affairs of the Village Government. Village Apparatus includes Village Head, Village Secretary, Village Technical Implementer, and Regional Implementer.

\subsection{Village Apparatus Capability}

Capability can be defined as a process carried out in increasing the expertise or capacity of a person, an organization, or a system to achieve the goals set. Capability is defined as the ability or competence that enables each individual, organization, network/sector, and broader system to carry out its functions. The meaning of capabilities is not limited to having skills (skill) but more than that, which is more understanding in detail. They genuinely master the ability from the point of weakness to how to overcome them. The indicators of capability, according to Agustina (2020), include:

a) Understanding, understand in carrying out its main tasks and functions

b) Skills, skillful in carrying out its main tasks and functions

c) Ability, able to carry out its main tasks and functions

From the explanation above, it can be concluded that capability is the expertise or ability possessed by an individual, organization, or system in carrying out its functions by adhering to efficiency, effectiveness, and sustainability following applicable regulations. Capability can be measured by three indicators, namely understanding, skills, and abilities. 


\subsection{Prior Research}

Amalya et al, which aims to examine and find empirical evidence regarding the influence of village apparatus capabilities, organizational commitment and implementation SISKEUDES on village financial management and its impact on accountability.

Widarnawati et al., (2018) which aims to analyze the influence of human resource competencies, organizational commitment, and community participation in village financial management and its impact on stakeholder confidence.

\subsection{Relationship between Village Apparatus Capability and Village Financial Management}

Village Apparatus capability can be interpreted as a measure of the ability of the Village Apparatus or Village Government in carrying out its functions. The ability in question can be in the form of power, strength, knowledge, intelligence, and expertise in analyzing and making decisions. Several factors can influence the high and low capabilities of the Village Apparatus. In a study conducted by Tjiptoherianto Asrori (2014), it was mentioned that the low workability is a result of the low level of education and training that is owned and the low level of health. The capabilities of the Village Apparatus are often associated with the process of village financial management. As village financial management actors, village officials are felt to need capabilities in carrying out their functions to achieve the goals set. Based on the description, the first hypothesis that can be formulated is: Ha1: Village Apparatus Capability has a positive effect on village financial management

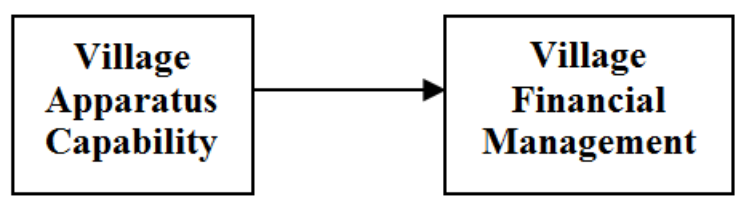

Fig. 1. Research Framework

\section{Research Methodology}

This study uses quantitative methods, The population in this study are institutions in the Perawas Village of Tanjung Pandan related to the village financial management process, namely the Village Government (Village Head and Village Apparatus), the Village Consultative Body (BPD), the Community Empowerment Institute (LPM) and the Village Owned Enterprises (BUMDesa) totaling 50 people. The study's object was carried out in Perawas Village, Tanjung Pandan District, Belitung Regency, Bangka Belitung Islands Province 2019. In this study, the technique used was nonprobability sampling. Researchers conducted data analysis through a statistical test tool using data processing tools such as SmartPLS version 3.2.8.

\section{Results and Discussions}

The hypothesis test of partial significance is used to determine each independent variable's effect on the dependent variable to answer whether the proposed hypothesis is accepted or 
rejected by looking at the value of the path coefficient of bootsrapping testing Widayat \& Probohudono, Agung (2016) Support for the idea can be seen by comparing the statistic with the $t$ table or comparing the $\mathrm{P}$ value with alpha. The hypothesis is accepted if the tstatistic value $>\mathrm{t}$ table or $\mathrm{P}$ value $<$ alpha 5 percent is 0.05 . The hypothesis testing in this study uses a one-tailed test model with a table of 1.66. Hypothesis test results are presented in the following Table:

Table 2. Path Coefficient Value Analyșis Bootsrapping

\begin{tabular}{|c|c|c|c|c|c|c|}
\hline Description & $\begin{array}{c}\text { Correlatio } \\
\mathbf{n}\end{array}$ & $\begin{array}{c}\text { Original } \\
\text { Sample } \\
\text { (Direction of } \\
\text { Relationship) }\end{array}$ & $\boldsymbol{t}_{\text {statistik }}$ & $\mathrm{t}_{\text {tabel }}$ & $\begin{array}{c}\text { P Value } \\
\text { (sig) }\end{array}$ & Decision \\
\hline Hipotesis 1 & $\mathrm{KA}>\mathrm{PK}$ & 0,922 & 26,70 & 1.66 & 0.000 & Signifikan \\
\hline
\end{tabular}

The hypothesis states that the capabilities of the Village Apparatus have a positive effect on village financial management. Based on Table IV.26, it is known that there is no significant positive relationship by the variable of Village Apparatus capability (KA) to village financial management (PK). Hypothesis testing shows a positive original sample value of 0.085 and a statistical value smaller than the Table that is $26,70<1.66$ and $\mathrm{P}$ value of $0.0,000>0.05$. Based on the values shown in Table 2, it can be concluded that $\mathrm{H}_{0}$ is rejected, and $\mathrm{H}_{1}$ is accepted. The contribution of the Village Apparatus capability variable to the village financial management variable is seen in the effect size value included in the small category which is valued at 0.017. Village Apparatus Capability has a positive effect on village financial management but does not significantly influence financial management in Perawas Village. This could be due to several factors, such as the level of village apparatus that is not yet good enough and the understanding of village financial management that is still lacking. Some factors that encourage this are the level of apparatus education in Perawas Village, especially the Village Treasurer, high school, and does not have an educational background related to the previous financial sector. Also, the training carried out by village officials, especially regarding financial management, was only attended by a handful of people, such as the Village Head, Village Secretary, Village Treasurer and Chairperson of the BPD, while the Section Chief responsible for making reports on the activities under him was not included in similar training.

Village Apparatus Capability is a measure of the Village Apparatus's knowledge, ability, and understanding in carrying out the established functions and responsibilities. The capabilities possessed by the Village Apparatus can be an essential benchmark in assessing the resulting performance related to the implementation of village financial management. Village officials who have a good understanding and capability will certainly carry out every stage of financial management effectively, efficiently, and economically, and can be accountable for their work by providing adequate and timely reporting to related parties.

\section{Conclusion}

Based on the results of research and discussion that has been described, the researcher concludes that: Village parental capability has a positive and significant effect on village financial management in the Desa Perawas of Tanjung Pandan, Belitung Regency, which means that the higher the powers of the Village Apparatus, the better performance will result. 


\section{Limitation And Study Forward}

Suggestions that can be given for further research are that further research is expected to broaden the research scope by adding research objects and focusing on one research object, for example in villages in the districts or districts. Analysis that raises the concept of "Financial Management Determinants" can also be carried out in the private sector to broaden the research scope to represent (generalize) other regions in the same Issue. Then increase the number of independent/ exogenous variables to strengthen the constructs explicitly built about Village financial management.

\section{Acknowledgement}

This research was conducted with financing from the Ministry of Risk Dikti through a beginner research scheme Beginner Lecturer Research in 2020. Thanks to the Ministry of Ristek Dikti, who has facilitated the implementation of this research, thanks to the majors, faculty and universities for support in this research's performance.

\section{References}

[1] E. Amalya, T., Akram, \& Pituringsih, 'Determinant of Village Financial Management and Its Implication toward Accountability (Study on Village Governance in West Lombok Regency', Int. J. Res. Advent Technol., vol. 5(12), 2017.

[2] Aryanti, 'Akuntabilitas Pengelolaan Keuangan Desa (Studi Kasus Pada Desa Di Kecamatan Simpang Rimba, Kabupaten Bangka Selatan)', Bangka Belitung, 2018.

[3] I. Meutia and Liliana, 'Pengelolaan Keuangan Dana Desa', J. Akunt. Multiparadigma, 2017, doi: 10.18202/jamal.2017.08.7058.

[4] T. Amalya, Akram, and E. Pituringsih, 'Determinant of Village Financial Management and Its Implication toward Accountability (Study on Village Governance in West Lombok Regency', Int. J. Res. Advent Technol., vol. 5, no. 12, 2017.

[5] B. W. Widarnawati, B. Santoso, and L. Suparman, 'Factors Affecting of Village Financial Management and Its Implications for Stakeholders Trust (Study on Villages in Central Lombok, Indonesia)', Int. J. Econ. Commer. Manag., 2018.

[6] Asrori, 'Kapasitas Perangkat Desa Dalam Penyelenggaraan Pemerintahan Desa Di Kabupaten Kudus', J. Bina Praja, vol. 6, no. 2, 2014.

[7] W. Widayat and N. Probohudono, Agung, 'Determinan Kesiapan Penerapan Sistem Akuntansi Berbasis Akrual Pada Pemerintah Daerah Di Indonesia', Simp. Nas. Akunt. Xix, Lampung 2016, 2016. 